\title{
Race Identity in Toni Morrison's Tar Baby
}

\author{
Messaoudi Walid \\ $\mathrm{PhD}$ Candidate \\ Literature/ Amman University \\ Amman, Jordon \\ waidmessaoudi@gmail.com
}

This paper aims at analyzing Toni Morrison's work Tar Baby. We are going to apply the postcolonial theory to deal with the issues of racial identity. Also, we are going to focus on the binary opposition as one of the main concern of post-colonialism to analyze the relationship between blacks and whites. This analysis is based on the actions, thoughts, and behaviors of the major characters to deal with the problem of racism and identity.

Keywords - Blacks, Whites, Racism, Identity

\section{Introduction}

Identity is a very recurrent theme in African American novels; because the search for identity is natural for every human being. From the very beginning of their presence in America, the black were subjected to slavery, their basic human rights have been often violated and they suffered from all forms of humiliation. Thus, the search of identity is pictured in the literary works. Writers such as Richard Wright in his novel Native Son dealt with 
the issues of identity and racism; Alice Walker in her novel The Color Purple is about women double discrimination and their identity troubles.

Toni Morrison is a prominent Afro-American writer; her well known novel Tar Baby represents the dilemma of identity. This issue shows its power as one of the main thematic concerns of African American literature. Her novels are deeply concerned with the issues of gender, race, slavery and identity. She has often been known as a voice of African American culture, and she addressed the position of African American person and specifically women in the contemporary world.

\section{Race Identity}

In abroad sense, post colonialism studies how European culture influences colonies in most fields. Also, it studies how these colonies react and resist the colonizer. Thus, the oppression imposed on them in different fields such as sociology, psychology and culture make them feel inferior. This inferiority makes them aware of being colonized and leads them to struggle for ethnic and self-governing. Moreover, the main focus of post-colonial theory is the binary opposition, which means the relation between colonized and colonizer, white and black, rich and poor.

\section{The Binary Opposition}

This term can be defined as the relationship of one to another and how they operate within a large society. Its problem is that it creates boundaries between them and leads to discrimination, each side seems like opposite to the other (Jakobsen, 1999).

In literature, binary opposition means exploring differences between groups of individuals like black and whites, male and female, high and low and so on (ibid). 
Luckily there was a night, three years ago, after he'd first settled into tropic life, when he woke up with a toothache so brutal it lifted him out of bed and knocked him to his knees. He knelt on the floor clutching the Billy Blass sheets and thinking, This must be a stroke. No tooth could do this to me. Directly above the waves of pain his left eye was crying while his right went dry with rage. He crawled to the night table and pressed the button that called Sydney.

(TB,ch1, p13)

Blacks were inferior to whites; thus, in the novel Valerian Street is the patron and Sydney was the butler. The binary opposition is shown through the act of Valerian street towards Sydney " pressed the button that called Sydney"(TB, ch1, p13), that shows him in a high position and at the same time shows Sydney in low position. The expression "press the button" Valerian uses to call Sydney like he is calling a machine and not a human being. Class differences are shown through the racist act of Valerian towards the black character Sydney.

\footnotetext{
"Mrs. Street awake?"

"I believe so. Anything else special you going to want for the holidays?"

“No. Just the geese. I won't be able to eat a bit of it, but I want to see it on the table anyway. And some more thalomide."

"You want Yardman to bring you thalomide? He can't even pronounce it."

"Write a note. Tell him to give it to Dr. Michelin."

"All right."
}

(TB, ch1,p16)

The idea of illiteracy is shown here so that yardman who is a black cannot read or even pronounce a word properly. As known that blacks were brought as slaves, only for work particularly in agriculture. Hence, this extract from the novel shows the ideology of Imperialism which means that the colonizer is shown as more educated, more civilized and 
superior. Blacks were considered uncivilized, narrow minded and harsh in both the way of thinking and behaving in comparison to whites:

Sydney returned with a bowl of crushed ice in which a mango stood. The peeling had been pulled back from the shiny fruit in perfect curls. The slits along the pulp were barely visible. Valerian yawned behind his fist, then said, "Sydney, can I or can I not order a cup of coffee andgetit?" "Yes, sir. 'Course you can." He put down the mango and filled Valerian's cup

(TB, ch1, p22)

In this quote Valerian ordered Sydney and uses the expression(can I or can I not order) to serve him and that shows him in a position of power, but not the way that harm or minimize from Sydney's dignity. Here, Valerian is the person who has the power over the black character Sydney, means that there are boundaries that oblige black person to act obediently because of the harsh reaction of white one in terms of race and discrimination.

Sydney (unbidden but right on time) removed the glass and placed a fresh white napkin over thewine spot. Then he collected the salad plates, replacing them with warm white china with a single band of gold around the edges.

(TB, ch3, p57)

This quote as well shows Sydney as inferior and as worker, because of his blackness; he does not interfere in their issues. The expression " unbidden but right on time" prove the differences; Sydney in this case is not waiting the orders whether to do or not, it becomes as a habit for him as a black servant which create the sense of differences between groups and individuals.

Margaret Lenore stared into the spaces and thought desperately of coffee, but she did not want toring up Sydney or Ondine, for that would begin the day she was not sure she wanted to participate in. She had had no 
sleep to speak of, and now, drained of panic, wavering between anger and sorrow,she lay in bed. Things were not getting better. She was not getting better. She could feel it and rightsmack in the middle of it, with Michael on his way, this had to happen: literally, literally a nigger in the woodpile.

(TB, ch4, p66)

Margaret is still shocked about the boy who was in her closet. She thinks about how things are not better, about how literally a "nigger" was in her closet. She calls him as "nigger"; this word shows her racist behavior mentality. She starts to think racially, considering the closet as a unclean place. She thinks about how she would better have to throw everything and buy new things. She thinks of the closet now as a toilet where something rotten had been and still was and thinks about how she would better have to throw everything and buy new things. Thus, Margaret's way of thinking proves the differences between the two binaries; blacks are less life position than whites.

"Well, then he can swim back. Now. Today. I'm not going to sleep with him in this house. If I had

known that I would have had a heart attack. All night I waited for that bastard Valerian to come up here and tell me what the hell was going on. He never showed."

"And Sydney was patrolling the halls with a gun. I thought he would have killed him by now."

"What does he think?"

"He's angry. Ondine's scared, I think."

"I'm going to have it out with Valerian. He's doing this just to ruin Christmas for me. Michael's coming and he knows I want everything right for him, and look what he does to get me upset. Instead of throwing that...that..." 


$$
\begin{aligned}
& \text { "Nigger." } \\
& \text { "Right, nigger, instead of throwing him right out of here." } \\
& \text { "Maybe we're making something out of nothing." }
\end{aligned}
$$

In this quote Jadine and Margaret are talking about the strange man. They discuss the black man and what to do about the whole situation. Margaret is mad at Valerian for letting the man stay. At one point she hesitates to call him "nigger" in front of Jadine, but Jadine volunteers to finish the sentence for her with "nigger" and then in another description she compares the man in her closet to a gorilla which makes Jadine uncomfortable and she tells Margaret that they are all scared and that they would have been equally scared if the man was white. Consequently, the white woman Margaret compares the black character to an animal because of his physical appearance and his unclean clothes and body which shows the concept of race and discrimination.

Yardman's face was nothing to enjoy, but his teeth were a treat. Stonewhite and organized like a drug store sample of what teeth ought to be.

(TB, ch1, p39)

Race is shown here via the description of physical and biological traits. The narrator describes the Yardman's teeth as good looking and his face as ugly. This description of his face goes in parallel with his occupation as well his blackness. So, the power of white racists leads blacks to be disabled to take care of their selves. The expression "nothing to enjoy" because of his blackness, which means that there is "something to enjoy" in the other race and here the binary opposition is completely shown between the two races.

The agency wouldlaugh her out of the lobby, so why was she and everybody else in the store transfixed? The height? The skin like tar against the canary yellow dress? The woman walked down the aisle as though her many-colored sandals were pressing gold tracks on the floor. 
Two upside-down $V$ 's were scored into each of her cheeks, her hair was wrapped in a gelée as yellow as her dress.

(TB, ch2, p41)

Again, there is another description of physical characteristics that shows the differences between races. The word "Tar" denotes the color of skin which is very dark. Here, Jadine finds her very attractive and follows her; she considers that this woman represents everything which embodies real blackness from her beauty to her clothes and marks in her face. Though her classy appearance, white race looks down upon her; this action shows the racism of white against black.

\section{Ambivalence}

Ambivalence refers to two racial groups that regard one another in a strange way. The white look to black as inferior and non-civilized, while black regard white as enviable and superior (Burton, 2004)

“And I am not a cook and I never have been. I don't want to see the kitchen. I don't like kitchens.”

"Why work yourself up this way every year? You know he'll disappoint you."

(TB, ch1, p23)

This quote shows the differences between races; Margaret completely opposes the idea of cooking or working in the kitchen. So, the feelings of being different or being other is shown here. In this quotation above, the author indicates that the white race never do black's works, and he will never be. Thus, Margaret totally opposed the idea of working in the kitchen, because she considers it like something not of her statues and her race.

They tell us what to eat. Who's working for who?"

"Whom. If you give Ondine menus for the whole week-that is exactly what she will prepare." 


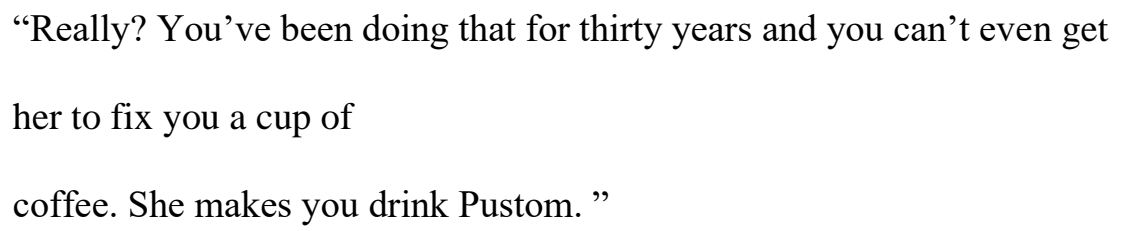

(TB, ch1, p21)

Again, there is another quote that shows the differences between the two oppositions, Ondine who is black and work for Margaret. There is a permanent clash between the two since a long time. Here, the behavior of Ondine proves the resistance of inferior blacks towards whites because of the oppression imposes on them. The black character Ondine feels the inferiority, so that, she is behaving in ambiguous way. Here, the concept of racism is shown through an act of ambivalence:

He went to the sideboard and lifted them onto plates. He laid stems of parsley on the right rim and two tomato slices to the left of each plate. He whisked away the fruit bowls, careful not to spill the water from the ice, and then leaned forward with the hot dish. Margaret frowned at the dish and waved it away. Sydney returned to the sideboard, put the rejected dish down and picked up the other.

(TB, ch1, p23)

Margaret here rejects the dish that Sydney brings to her in a harsh way. Although the mistreating of Margaret towards Sydney he keeps serving them. This rejection of the dish shows the power of the other (colonizer). This quote shows ambivalence of behavior between the high state of whites and the low state of black character; the black character here is under power of white. Thus, the superiority of whites is the main reason for blacks' behavior.

Sydney (unbidden but right on time) circled the table with steps as felt as blackboard erasers. He kept his eyes on the platter, or the table setting, or his feet, or the hands of those he was serving, and never made eye contact with any of them, including his niece.

(TB, ch3, p50) 
Here Sydney behaves in ambiguous way when he serves them without looking in their faces; this shows the ambivalence of two races. Thus, each one of the races is using his own way of resistance. Here, Sydney who is black behaving in a way that shows his complete rejection to what he is doing; means that he is not happy with such state of being a servant and at the same time he is resisting his desire. The black character and the white character show the racist view through the ambivalence of behavior.

Jadine sighed. She wanted to leave the table, but didn't know how. Does he want me to stay or doesn't he? she wondered. Does he want me to talk or doesn't he? All I can do is ask polite questions and urge him to talk if he feels like it. Maybe I should go to Margaret, or change the subject, or have my head examined for coming here. "No one asks you to be," she said softly.

(TB, ch3, p58)

Here Jadine is careful in her discussion with Valerian; this caution emerges through her position in comparison to him. Thus, this carefulness shows Valerian as other and superior to her. The ambivalence of the two races is shown here, blacks who are inferior to their counterpart whites. This behavior of Jadine shows the differences between classes, though Jadine is considering herself one of them but her color of skin makes her inferior whether she behaves like them or not.

"It's all right, Ondine. Lucky you had one."

"I'll say. Even the colored people down here don't eat mangoes."

"Sure they do." Sydney slipped a napkin from its ring. The pale blue linen complemented his

mahogany hands.

(TB, ch1, p32) 
This dialogue between Ondine, Sydney and Yardman shows the signs of being marginalized and being a minority, so that, they are not allowed to eat such kind of fruits. The concept of discrimination is shown here, blacks and whites are not alike. This marginalization creates a sort of resistance between the two races. Whites who are the oppressors and blacks who are the victims, they are deprived from such kind of fruits through a racist act.

\section{Hybridity and Identity:}

Hybridity refers to the state of when the colonizer gets out from the country, then, the colonized man affected a lot by the colonizer's past behavior, conviction or what is so called neo-colonialism (Ashcroft, Griffiths, \& Tiffin, 1995).

Jadine loosened the straps of her halter and fanned her neck. "Well, let me tell you your face is prettier than your kitchens." Ondine smiled. "Look who's talking. The girl who modeled for Karen."

"Caron, Nanadine. Not Karen."

“Whatever. My face wasn't in every magazine in Paris. Yours was. Prettiest thing I ever saw. Made those white girls disappear. Just disappear right off the page."

(TB, ch1, p37)

This quote shows the traits of hybridity, means that "colonized" is behaving the same way as the "colonizer". When Ondine praises Jadine because she appears in the first pages of magazines in Paris, which means that a black poor girl that originate from slave ancestors in a European white society honored with this honor of being a model. Thus, through her praising for Jadine she is defining herself and proud of her belief among others (whites). The black character (who is the oppressed one) is behaving the same way that white character( who is the oppressor) do, so that, blacks are imitating whites' behaviors as a consequence of the oppression and the effect of racism imposed on them. 
Identity on the other hand relates to the way individuals define themselves. Also, it relates to the person's self-concept (McCarthy, 2013).

It was. Actually it was good he made me think about myself that way, at that place. He might have convinced me if we'd had that talk on Morgan Street. But in Orange County on a hundred and twenty acres of green velvet?" She laughed softly. "Can you believe it? He wanted us to go back to Morgan Street and be thrilling." "Us? He was going with you?" "Just to get us started. He meant us Blacks: Sydney, Ondine and me."

(TB, ch3, p60)

The pronoun "us" shows that they are proud of being blacks. They define their selfconcepts and their identity, though Jadine is considering herself not one of them. Jadine was living in Europe but she does not forget her origin of being black. The black protagonist Jadine finds herself helpless to deny her identity, changing the place or the homeland does not mean to exchange or replace your identity. Identity is something that cannot be separate from one's mind. Also, identity is not something to be affected by racism or discrimination.

The woman appeared simply at a time when she had a major decision to make: of the three raucous men, the one she most wanted to marry and who was desperate to marry her was exciting and smart and fun and sexy...so? I guess the person I want to marry is him, but I wonder if the person he wants to marry is me or a black girl? And if it isn't me he wants, but any black girl who looks like me, talks and acts like me, what will happen when he finds out that I hate ear hoops, that I don't have to straighten my hair, that Mingus puts me to sleep, that sometimes I want to get out of my skin and be only the person inside — not American — not black-just me?

(TB, ch2, p42) 
In this quote, Jadine who is one of the major characters is confused about her identity whether she is black or white, African or American. She is thinking about the right man that she wants to be with him. She is concerned however that he wants to marry her only because she is black while in truth she rejects all forms of blackness and black culture and that she sometimes even wishes she could get out of her skin so as not to be black or American but just herself. She ran away to the island after that because Ryk is white and the woman in yellow dress made her think about her identity so she decided to go to her aunt and uncle to take their opinion. In fact, she is defining her identity as being black although she is living inside a white European society. She is not sure about her position, so that she is still considered as black minority. The black protagonist Jadine has doubts about her relationship with the white boy as a result of the racism imposed on her.

Within the question of identity we can discuss ethnicity which is incorporation of traits like values, belief, behavior, memories, experience and loyalties belong to a specific group of community.

"Mango all right?" she asked without turning her head.

"She ate a mouthful," said Sydney.

"Contrary," murmured his wife. She poured the eggs into a shallow buttered pan, and stirred them slowly with a wooden spoon.

"It's all right, Ondine. Lucky you had one."

"I'll say. Even the colored people down here don't eat mangoes."

"Sure they do." Sydney slipped a napkin from its ring. The pale blue linen complemented hismahogany hands.

"Yardmen," said Ondine. "And beggars."

(TB, ch1, p32) 
In this quote when Ondine ate from the mangoes fruits in front of Yardman ,forgetting that those workers are deprived or not allowed to eat mangoes. Ondine at that moment remembers her belief and her origin though she is the butler's wife, so that can do whatever she wants. Thus, being in high position does not mean to forget your ethnic identity. Consequently, blacks are a minority and within this minority there is a classification of peoples like the case of the black Ondine who is the butler's wife and the black yardman. Blacks are aware of the racism behaviors towards them, but they never forget about their racial and ethnic origin.

Identity and ethnicity are much related to diaspora. This term refers to the people who enforced to migrate from their nature homeland. In literature diaspora has a relation which the question if people save let their identity culture, religion, language while they are in another country or culture (Ashcroft, Griffiths, \& Tiffin, 1995)

"Ondine dreaming of sliding into water, frightened that her heavy legs and swollen ankles will sink her. But still asleep she turns over and touches her husband's back — the dream dissolves and with it the anxiety. He is in Balti moreno was usual and because it was always a red city in his mind — red brick, red sun, red neck sand cardinals — his dream of it now was rust-colored. Wagons, fruit stands, all rust-colored. He had left that city to go to Philadelphia and there he became one of those industrious Philadelphia Negroes - the proudest people in the race"

(TB, ch2, p49)

Sydney here is dreaming about his homeland and he feels diasporic. Diaspora is one element of post colonialism which means enforcing individuals to migrate from their homeland. This feeling of Sydney is a quest for identity as well; he feels that he does not belong to this country though he is living in it since long time. Here, the black character 
Sydney feels nostalgic to the place who belongs, where the place of all black, so that, there is no kind of racism, oppression or discrimination.

\section{Conclusion}

In this paper we have focused on a deep analysis of the novel on hand. We have extracted many quotes that fulfill our concern. We have deduced that race identity is strongly shown through the author's depiction of the main characters. A collection of characters who are completely different from each other in terms of skin color on the first place. Thus, this difference creates a sort of binaries and ambivalences under the name of racism. 


\section{Works Cited}

Ashcroft, Bill, et al. The Post-Colonial Studies Reader. Routledge, 1995.

Jakobsen, Janet R. Working Alliances and the Politics of Difference: Diversity and Feminist Ethics. NetLibrary, Inc., 1999.

Mays, Benjamin E., and Orville Vernon Burton. Born to Rebel An Autobiography. University of Georgia Press, 2003.

McCarthy, Cameron. Race, Identity and Representation in Education. Verlag Nicht Ermittelbar, 2013.

Morrison, Tony. Tar Baby. Random House, 1981.

Walker, Alice. The Color Purple. London: Women's Press, 1992.

Wright, Richard, and Caryl Phillips. Native Son. Vintage Digital, 2016. 